\title{
PEMANFAATAN BERBAGAI DOSIS PENYULINGAN NILAM DAN KOTORAN KAMBING PADA PERTUMBUHAN VASE VEGETATIF TANAMAN KEDELAI DI KOTA PALOPO
}

\author{
Utilization of Various Patchouli Distillation Dosages and Goat Dung in the Growth of \\ Vegetative Vases of Soybean Plants in Palopo City \\ Eka Sudartik ${ }^{1}$ dan Mawar Pasoloran ${ }^{2}$ \\ Emai : ekasudartik@gmail.com
}

Program Studi Agroteknologi, Fakultas Pertanian, Universitas Cokroaminoto Palopo ${ }^{12}$

\begin{abstract}
Abstrak
Penelitian ini bertujuan untuk mengetahui efektivitas pemanfaatan limbah penyulingan nilam dan kotoran kambing terhadap pertumbuhan dan hasil tanaman kedelai. Dilakukan di lahan percobaan kampus II Fakultas Pertanian Universitas Cokroaminoto Palopo, Jalan Lamaranginang, Kelurahan Batupasi, Kecamatan Wara Utara, Kota Palopo, pada bulan Desember 2018 sampai April 2019. Rancangan percobaan yang digunakan pada penelitian ini adalah rancangan acak kelompok. Percobaan ini terdiri dari 6 perlakuan, setiap perlakuan terdiri dari 4 ulangan, sehingga terdapat 24 unit percobaan. Adapun dosis yang diberikan pada setiap perlakuan adalah sebagai berikut: $P 0$ : (Tanpa perlakuan), P1 :( 5 gram LPN +25 gram kotoran kambing $), P 2:(10$ gram LPN +20 gram kotoran kambing), $P 3:$ (15 gram LPN + 15 gram kotoran kambing), P4 : (20 gram LPN + 10 gram kotoran kambing), P5 : (25 gram $L P N+5$ gram kotoran kambing).
\end{abstract}

Kata kunci: limbah penyulingan nilam, kotoran kambing, tanaman kedelai

\section{Abstract}

This study aims to determine the effectiveness of the utilization of patchouli distillation waste and goat manure on the growth and yield of soybean plants. Conducted on the experimental field campus II Faculty of Agriculture, University of Cokroaminoto Palopo, Jalan Lamaranginang, Batupasi Village, Wara Utara District, Palopo City, from December 2018 to April 2019. The experimental design used in this study was a randomized block design. This experiment consisted of 6 treatments, each treatment consisting of 4 replications, so there were 24 experimental units. The dosages given at each treatment are as follows: P0: (without treatment), P1: (5 grams LPN + 25 grams goat manure), P2: (10 grams LPN + 20 grams goat manure), P3: (15 grams LPN + 15 grams of goat manure), P4: (20 grams of $L P N+10$ grams of goat manure), P5: (25 grams of LPN +5 grams of goat manure).

Keywords: patchouli distillation waste, goat manure, soybean plants

\section{PENDAHULUAN}

Kedelai adalah salah satu tanaman polong-polongan dan merupakan sumber utama protein dan minyak nabati utama dunia. Kedelai merupakan tanaman pangan utama strategis terpenting setelah padi dan jagung. Begitu besarnya konstribusi kedelai dalam hal penyediaan bahan pangan bergizi bagi manusia sehengga kedelai bisa dijuluki
Gold from the Soil, atau sebagai World's Miracle mengingat kualitas asam amino proteinnya yang tinggi, seimbang dan lengkap. Konsumsi kedelai oleh masyarakat di Indonesia dipastikan akan terus meningkat beberapa pertimbangan seperti bertambahnya populasi penduduk, peningkatan pendapatan per kapita, 
kesadaran masyarkat akan gizi makanan. Peningkatan kebutuhan akan kedelai dapat dikaitkan dengan meningkatnya konsumsi masyarakat terhadap tahu dan tempe, serta untuk pasokan industry kecap (Mursida, 2005).

Berdasarkan Badan Pusat Statistik (BPS) menyebut produksi kedelai di indonesia pada tahun 2013 sebanyak 779.992 ton dan pada tahun 2014 sebanyak 954.997 ton. Peningkatan produksi kedelai dari tahun 2013 sampai 2014 sebanyak 175.005 ton. Sedangkan pada tahun 2015 kedelai yang dihasilkan sebanyak 963.183 ton. Hal ini menunjukkan pada tahun 2015 produksi kedelai mengalami peningkatan sebanyak 8.186 ton dari tahun 2014 (BPS, 2015).

Peningkatan produksi kedelai yang ada di atas tidak berbanding lurus dengan keadaan di lapangan dimana permintaan kedelai lokal ditingkat pasar selalu tidak terpenuhi. Akibatnya pemerintah sampai saat ini masih melakukan impor kedelai dari berbagai negara.

Berdasarkan Pusat Data dan Sistem Informasi Pertanian yang menyatakan bahwa sepanjang tahun 1980-2015 tercatat volume impor kedelai mengalami fluktuatif dan menunjukkan peningkatan, dengan ratarata pertumbuhan $25,33 \%$ pertahun.
Peningkatan volume impor sangat signifikan pada tahun 1983 sebesar 347,72\% dan tahun 1999 sebesar 116\%. Diantara tahun-tahun tersebut terjadi penurunan volume impor tetapi secara presentasi tidak terlalu signifikan. Volume impor tertinggi terjadi pada tahun 2015 sebesar 6,42 juta ton (Riniarsi, 2016).

Selain masalah diatas salah satu penyebab rendahnya produksi kedelai lokal yaitu setiap tahunnya lahan semakin berkurang dan kualitas tanah semakin menurun. Sehingga menyebabkan minimnya unsur hara di dalam tanah. Salah satu alternatif untuk menyelesaikan permasalahan di atas yaitu dengan cara memanfaatkan limbah penyulingan nilam dan kotoran kambing. Berdasarkan penelitian sebelumnya dilaporkan bahwa kandungan hara di dalam kompos limbah nilam khususnya kadar $\mathrm{N}$ cukup tinggi yaitu 3,59\% (Djazuli, 2002b). Status hara N dan K kompos limbah nilam tersebut lebih tinggi dibandingkan pupuk kompos asal pasar (Tombe et al., 2001). Selain itu, pada penelitian sebelumnya menyatakan bahwa Kotoran kambing memiliki keunggulan dalam hal kandungan unsur hara. kotoran kambing mengandung 1,26\% N, 16,36 Mg. $\mathrm{kg}^{-1}$ P, 2,29 Mg.L.1 Ca, Mg dan 4,8\% C-organik (Arsyad $d k k ., 1975)$. 
METODOLOGI PENELITIAN

Tempat dan Waktu

Penelitian ini dilaksanakan diLahan

PercobaanFakultas Pertanian Kampus

IIUniversitas Cokroaminoto Palopo di

Kelurahan Batupasi, Kecamatan Wara

Utara, Kota Palopo. Mulai bulan November 2019 sampai selesai.

\section{Bahan dan Alat}

Bahan yang digunakan dalam penelitian ini adalah benih kedelai varietas limbah penyulingan nilam, kotoran kambing, EM4, dan air. Alat yang digunakan adalah anjasmoro, terpal, ember, pulpen, spidol, kertas, kamera, meteran dan mistar.

\section{Metode Penelitian}

Penelitian ini menggunaka metode Rancangan Acak Kelompok (RAK) dengan 6 perlakuan dan diulang sebanyak 4 kali. Sehingga terdapat 24 satuan percobaan. Dimana masing-masing perlakuan tersebut adalah sebagai berikut:

P0 : Tanpa perlakuan

P1 : $30 \mathrm{~g}$ / tanaman ( 5 gram LPN+25 gram kotoran kambing)

$\mathrm{P} 2: 30 \mathrm{~g} /$ tanaman (10 gram LPN+20 gram kotoran kambing)

P3 : $30 \mathrm{~g} /$ tanaman (15 gram LPN+15 gram kotoran kambing)
P4 : $30 \mathrm{~g}$ / tanaman (20 gram LPN+10 gram kotoran kambing)

P5 : $30 \mathrm{~g} /$ tanaman (25 gram LPN+5 gram kotoran kambing)

Data yang diperoleh dianalisis secara statistik dengan menggunakan sidik ragam. Apabila sidik ragam menunjukkan pengaruh nyata, maka dilakukan uji Beda Nyata Terkecil (BNT).

\section{Pelaksanaan Penelitian}

1. Pengambilan limbah penyulingan nilam Pengambilan limbah penyulingan nilam dilakukan di pabrik tempat penyulingan. Pengambilan limbah ini menggunakan skop yang kemudian dikumpulkan dalam satu wadah karung. Limbah nilam yang digunakan dalam penelitian ini adalah limbah yang sudah terdekomposisi. Limbah penyulingan nilam yang sudah terdekomposisi akan mudah terurai dalam tanah dan unsur nitrogennya bisa diserap tanaman dengan mudah.

2. Fermentasi kotoran kambing

Fermentasi kotoran kambing dilakukan dengan menggunakan campuran EM4, air dan molase yang sebelumnya telah didiamkan selama dua hari agar bakteri dalam EM4 aktif. Kemudian larutan yang berisi EM4, air dan molase disiramkan hingga merata ke kotoran kambing yang hendak dibuat kompos. Kemudian ditutup 
rapat kurang lebih 1-2 minggu, selama proses pengomposan sesekali dibolak balik.

\section{Penanaman}

Penanaman dengan membuat lubang tanam memakai tugal dengan kedalaman antara1,5-2 $\mathrm{cm}$. Setiap lubang tanam diisi sebanyak 2 biji. Kebutuhan benih yang optimal dengan daya tumbuh lebih dari $90 \%$ yaitu 50-60 kg/ha. Penanaman dilakukandengan menggunakan jarak tanam $40 \mathrm{~cm} \times 10-1 \mathrm{~cm}$. Pada lahan subur, jarak dalambarisan dapat diperjarang menjadi 15$20 \mathrm{~cm}$.

\section{Aplikasi}

Aplikasi kompos limbah penyulingan nilam dan kotoran kambing dilakukan tiga kali yaitu satu minggu sebelum penanaman. Aplikasi pertama sebelum penanaman bertujuan untuk memacu pertumbuhan benih tanaman dengan dosis masing-masing perlakuan. Aplikasi kedua dilakukan 20 HST, aplikasi kedua bertujuan untuk memacu pertumbuhan bunga dan aplikasi ketiga 45 HST,

\section{Parameter Pengamatan}

1. Tinggi tanaman $(\mathrm{cm})$

2. Diameter tanaman $(\mathrm{cm})$

3. Jumlah daun (helai)

\section{HASIL DAN PEMBAHASAN 1. Tinggi Tanaman $(\mathrm{cm})$}

Rata-rata tinggi tanaman dalam hasil pengamatan tinggi tanaman kedelai memperlihatkan pengaruh tidak nyata terhadap pemberian limbah penyulingan nilam dan kotoran kambing (Gambar 2).

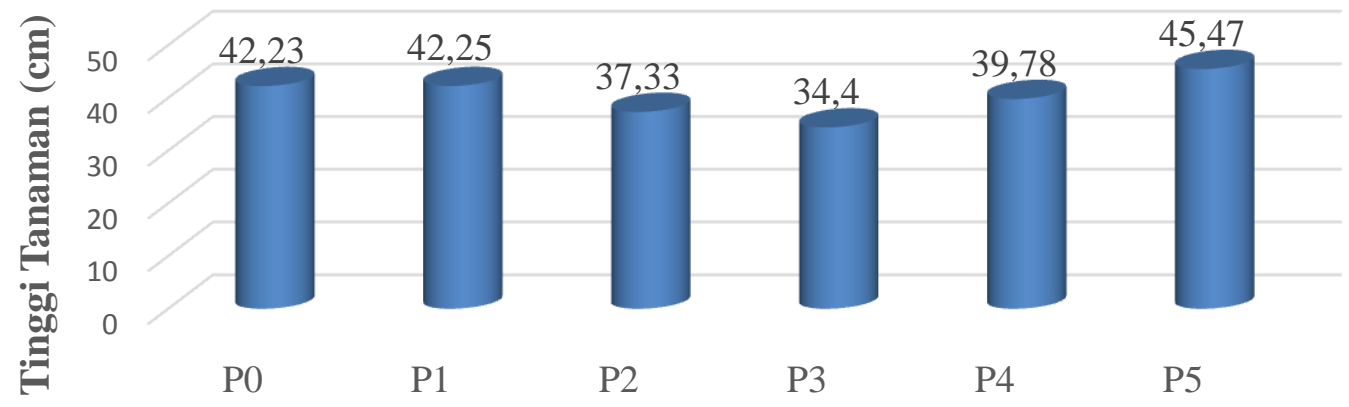

\section{Perlakuan}

Gambar 2. Diagram Rata-rata Tinggi Tanaman Kedelai Terhadap Pemberian Limbah Penyulingan Nilam dan Kotoran Kambing.

Diagram di atas memperlihatkan bahwa pemberian limbah penyulingan nilam dan kotoran kambing terhadap pertumbuhan tanaman kedelai, menghasilkan tinggi tanaman terbaik yaitu pada perlakuan P5 30 g/ tanaman (25 gram LPN + 5 gram kotoran 
kambing) dengan rata-rata $45,475 \mathrm{~cm}$ dan tidak terpaut jauh dengan perlakuan P1 $30 \mathrm{~g} /$ tanaman ( 5 gram LPN +25 gram kotoran kambing) dengan nilai rata-rata $42,2525 \mathrm{~cm}$ dan P0 (tanpa perlakuan) dengan rata-rata tinggi tanaman 42,2375 cm. Pada perlakuan P4 $30 \mathrm{~g}$ / tanaman (20 gram LPN + 10 gram kotoran kambing) nilai rata-rata $39,7875 \mathrm{~cm}$, pada perlakuan P2 $30 \mathrm{~g} /$ tanaman (10 gram LPN + 20 gram kotoran kambing) nilai ratarata $37,3375 \mathrm{~cm}$, dan rata-rata tinggi tanaman yang paling rendah yaitu pada perlakuan P3 $30 \mathrm{~g} /$ tanaman (15 gram LPN + 15 gram kotoran kambing) dengan nilai rata-rata $34,4 \mathrm{~cm}$.

\section{Diameter Batang (mm)}

Berdasarkan diagram pengamatan diameter batang tanaman kedelai di bawah ini memperlihatkan pengaruh tidak nyata terhadap pemberian limbah penyulingan nilam dan kotoran kambing (Gambar 3).

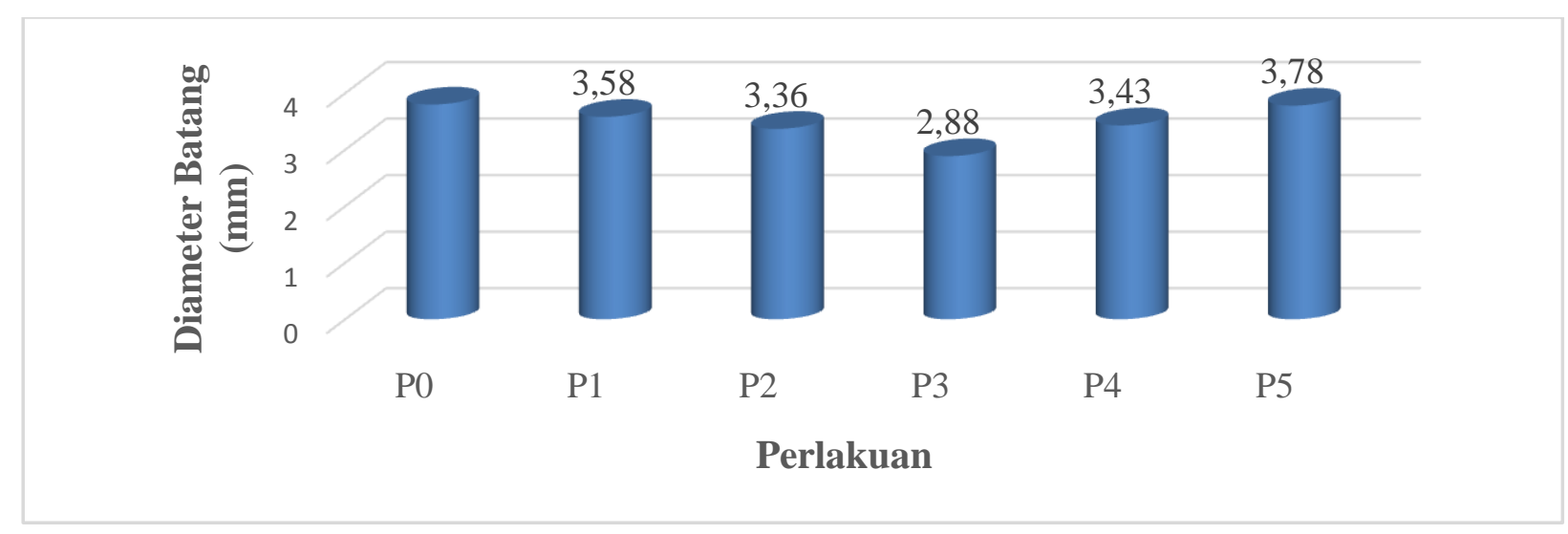

Gambar 3. Diagram Rata-rata Diameter Batang Tanaman Kedelai Terhadap Pemberian Limbah Penyulingan Nilam dan Kotoran Kambing.

Diagram di atas memperlihatkan diameter batang pada tanaman kedelai dengan setiap pemberian limbah penyulingan nilam dan kotoran kambing berbeda-beda pada setiap perlakuan. Diameter batang tanaman kedelai yang tertinggi yaitu pada pemberian limbah penyulingan nilam dan kotoran kambing pada perlakuan P0 (tanpa perlakuan) dengan nilai rata-rata $3,8 \mathrm{~mm}$. sedangkan pada perlakuan P5 $30 \mathrm{~g} /$ tanaman (25 gram LPN + 5 gram kotoran kambing) dengan nilai rata-rata 3,78125 $\mathrm{mm}$. pada perlakuan P1 30 g/ tanaman ( 5 gram LPN +25 gram kotoran kambing) dengan nilai rata-rata 3,58125 $\mathrm{mm}$, tidak terpaut jauh dengan perlakuan P4 $30 \mathrm{~g} /$ tanaman (20 gram LPN +10 gram kotoran kambing) dengan nilai rata-rata 3,43125 mm. Perlakuan P2 $30 \mathrm{~g} /$ tanaman (10 gram LPN + 20 gram kotoran kambing) 
Fakultas Pertanian Universitas Cokroaminoto Palopo

dengan nilai rata-rata $3,36875 \mathrm{~mm}$. Rata-rata diameter batang tanaman kedelai terendah yaitu pada perlakuan P3 $30 \mathrm{~g} /$ tanaman (15 gram LPN + 15 gram kotoran kambing) dengan nilai rata-rata $2,8875 \mathrm{~mm}$.
Berdasarkan diagram pengamatan jumlah daun tanaman kedelai di bawah ini memperlihatkan pengaruh tidak nyata terhadap pemberian limbah penyulingan nilam dan kotoran kambing (Gambar 4).

\section{Jumlah Daun (helai)}

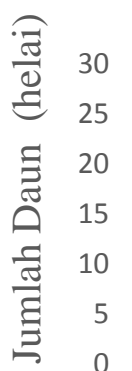

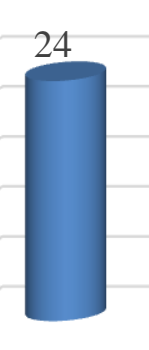

P0

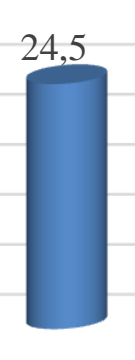

P1

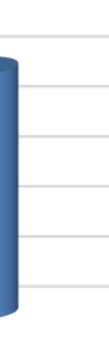

P2

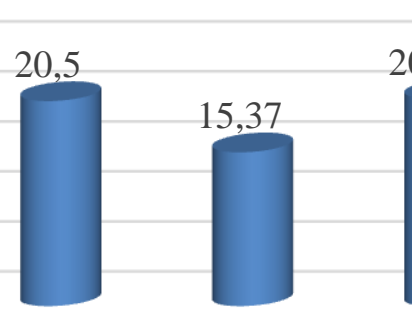

P3
27

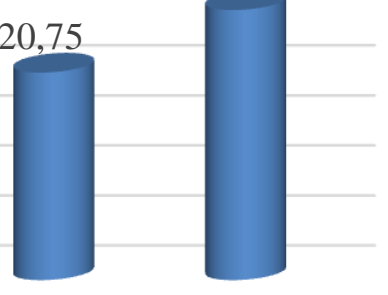

P4

P5

\section{Perlakuan}

Gambar 4. Diagram Rata-rata Jumlah Daun Tanaman Kedelai Terhadap Pemberian Limbah Penyulingan Nilam dan Kotoran Kambing.

Diagram di atas memperlihatkan jumlah daun tanaman kedelai dengan setiap pemberian limbah penyulingan nilam dan kotoran kambing yang berbeda-beda pada setiap perlakuan. Jumlah daun tanaman kedelai yang tertinggi terhadap pemberian limbah penyulingan nilam dan kotoran kambing $30 \mathrm{~g} /$ tanaman (25 gram LPN + 5 gram kotoran kambing) yaitu pada perlakuan P5 dengan nilai rata-rata 27 helai. Sedangkan pemberian limbah penyulingan nilam dan kotoran kambing $30 \mathrm{~g} /$ tanaman ( 5 gram LPN + 25 gram kotoran kambing) yaitu pada perlakuan $\mathrm{P} 1$ dengan nilai ratarata 24,5 helai, tidak terpaut jauh dengan perlakuan P0 (tanpa perlakuan) yaitu dengan nilai rata-rata 24 helai. Perlakuan P4 30 g/ tanaman (20 gram LPN + 10 gram kotoran kambing) dengan nilai rata-rata 20,75 helai, tidak terpaut jauh dengan perlakuan P2 $30 \mathrm{~g} /$ tanaman (10 gram LPN + 20 gram kotoran kambing) dengan nilai rata-rata 20,5 helai. Sedangkan rata-rata jumlah daun terendah yaitu pada perlakuan P3 $30 \mathrm{~g} /$ tanaman (15 gram LPN + 15 gram kotoran kambing) dengan nilai rata-rata 15,375 helai. 


\section{Pembahasan}

Berdasarkan hasil analisissidik ragam pemberian limbah penyulingan nilam dan kotoran kambing terhadap pertumbuhan dan hasil tanaman kedelai pada parameter tinggi tanaman, diameter batang, jumlah daun, umur berbunga, berat segar dan berat kering tidak memberikan pengaruh yang nyata terhadap tinggi tanaman. Berdasarkan hasil pengamatan tinggi tanaman pada perlakuan P5 dengan dosis $30 \mathrm{~g} /$ tanaman (25 gram LPN+5 gram kotoran kambing), menunjukkan hasil dengan nilai rata-rata $45,475 \mathrm{~cm}$ hal ini dikarenakan pada perlakuan P5 menggunakan dosis tertinggi pada penggunaan limbah penyulingan nilam yang dikombinasi dengan 5 gram kotoran kambing sehingga dapat mempengaruhi tinggi tanaman. Kemudian pada perlakuan P3 dengan dosis $30 \mathrm{~g} /$ tanaman (15 gram LPN+15 gram kotoran kambing) menunjukkan tinggi tanaman terendah dengan rata-rata tinggi tanaman $34,4 \mathrm{~cm}$. Menurut Dzajuli (2002b) kandungan hara di dalam kompos limbah nilam khususnya kadar N cukup tinggi yaitu 3,59\%. Sanchez (1976) mengatakan unsur hara paling banyak dibutuhkan tanaman adalah nitrogen, fosfor, dan kalium.Menurut Syafrudddin, Nurhayati, Wati (2012) dalam pendra (2013), menyatakan bahwa untuk dapat tumbuh dengan baik tanaman membutuhkan hara N,P dan K dalam jumlah yang cukup, yang merupakan unsur hara esensial dimana unsur hara ini sangat berperan dalam pertumbuhan tanaman secara umum pada fase vegetatif.

Berdasarkan hasil analisissidik ragam pemberian limbah penyulingan nilam dan kotoran kambing terhadap pertumbuhan dan hasil tanaman kedelai pada parameter diagram diameter batang diatas memperlihatkan tidak berpengaruh nyata terhadap diameter batang tanaman kedelai. Tanaman yang menunjukkan diameter batang terbaik yaitu pada perlakuan P0 (tanpa perlakuan) dengan nilai rata-rata 3,8 mm. Sedangkan diameter batang terendah terdapat pada perlakuan P3 dengan dosis 30 g/ tanaman (15 gram LPN+15 gram kotoran kambing) dengan nilai rata-rata 2,8875 mm. Hal ini disebabkan karena pada perlakuan P0 tidak terjadi genangan pada saat air laut naik. Pada penelitian ini dilakukan pada bulan desember hingga april cuaca di daerah palopo sering turun hujan yang mengakibatkan air laun naik. menurut Pambudi (2013) menyatakan bahwa tanaman kedelai akan tumbuh baik jika ditanam di daerah beriklim kering.

Hasil analisis sidik ragam menunjukkan bahwa efektivifitas 
pemanfaatan limbah penyulingan nilam dan kotoran kambing tidak berpengaruh nyata pada jumlah daun. Diperoleh hasil pengamatan jumlah daun terbaik pada perlakuan P5 dengan dosis $30 \mathrm{~g} /$ tanaman (25 gram LPN+5 gram kotoran kambing) memiliki nilai rata-rata 27 helai. Sedangkan jumlah daun terendah pada perlakuan P3 dengan nilai rata-rata 15,375 helai. Hal ini disebabkan karna pada perlakuan P5 kebutuhan unsur hara cukup. Menurut Lingga (2005) menyatakan bahwa nitrogen dalam jumlah yang cukup berperan dalam mempercepat pertumbuhan tanaman secara keseluruhan khususnya batang dan daun tanaman.

\section{KESIMPULAN}

Berdasarkan hasil penelitian yang telah dilakukan, maka dapat diambil kesimpulan bahwa pada parameter tinggi tanaman, umur berbunga, berat segar dan berat kering. Dosis pupuk pada perlakuan P5 30g/ tanaman (25 gram LPN+5 gram kotoran kambing) dengan nilai rata-rata 45,475 cm, diameter batang terbaik pada perlakuan P0 (tanpa perlakuan) dengan nilai rata-rata $3,8 \mathrm{~mm}$, jumlah daun terbaik pada perlakuan P5 dengan nilai rata-rata 27 helai,

\section{DAFTAR PUSTAKA}

Arsyad, S., Kaban, N., Sukmana, S. 1975. Fisika tanah: dasar-dasar sifat fisik dan proses. IPB Press. Bogor.

BPS. 2015. Table dinamis Produksi kedelai di indoseia dan Sulawesi selatan. https://www.bps.go.id/site/resultT $a b$. Dakses pada tanggal 23 Oktober 2018.

Dzajuli M. 2002b. Pengaruh Aplikasi Kompos Limbah Penyulingan Nilam Terhadap Pertumbuhan Dan Produksi Tanaman Nilam (Pogostemon cablin L.). Prosiding Seminar Nasional Dan Pameran Pertanian Organik. Jakarta, 2-3 juli 2002.

DJazuli, M. 2000. Pengaruh Aplikasi Kompos Limbah Penyulingan Minyak Nilam Terhadap Pertumbuhan Dan Produksi Tanaman Nilam (Pogostemon cablin L.) Prosiding Seminar Nasional Dan Pameran Pertanian Organik. Jakarta.

Lingga. 2005. Petunjuk Penggunaan Pupuk. Penebaran Swadaya. Jakarta.

Mursida. 2005. Perkembangan produksi kedelai nasional dan upaya pengembangannya di provinsi Kalimantan timur. Kalimantan: LIPL.

http://isjd.pdii.lipi.go.id/admin/jur nal/20054146.pdf. Diakses pada tanggal 25 Oktober 2018.

Pambudi, singgih. 2013. Budidaya dan Khasiat Kedelai Edamame Cemilan Sehat dan Lezat Multi Manfaat. Yogyakarta: Penerbit Pustaka Baru. 
Pendra. 2013. Pengaruh Pupuk Organic Cair Terhadap Pertumbuhan Dan Hasil Beberapa Varietas Kacang Hijau (Phaseolus Radiates L.). Fakultas Pertanian Universitas

Tamansiswa. Padang.

Riniarsi Dyah. 2016. Komuditas pertanian sub sector tanaman pangan. Pusat data dan sistem informasi pertanian kementrian pertanian. http://epublikasi.

setjen.pertanian.go.id/epublikasi/ outlook/2016/Tanpang/OUTLOO

K\%20KEDELAI\%202016/files/as sets/common/downloads/OUTLO OK\%20KEDELAI\%202016.pdf.

Diakses pada tanggal 25 Oktober 2018.

Sanchez, P.A. 1976. Properties And Management of Soil In The Tropic. John Wiley and Sons, Inc. New York.

Tombe M, K Mulya, R Zaubin, ER Pribadi, C Indrawanto, O Trisilawati dan A Ruhnayat. 2001. Uji coba pemanfaatan dan peningktan mutu kompos produksi pilot plan klender, berikut pemasarannya. Final Report. PT Gas Negara dan Balittro. (unpublished). 